\title{
Society organization, not pathogenic viruses, is the fundamental cause of pandemics
}

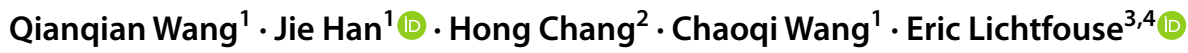

Published online: 30 October 2021

(C) The Author(s), under exclusive licence to Springer Nature Switzerland AG 2021

In cases of emergencies such as pandemics, it is common sense-and somewhat too easy-to design a culprit or enemy, e.g., a pathogenic virus, to be fought and eradicated, thus lessening the human responsibility of the issue. This is the classical strategy of the occidental world where the most diseases and other problems are mainly tackled by treating the symptoms, thus largely overlooking the profound causes (Lichtfouse 2009, 2010). There is now mounting evidence that societal and environmental factors have largely contributed to the coronavirus disease 2019 pandemic (COVID-19). For instance, since pathogens are occurring widely in nature, one might hypothesize that the pandemic would never have happened without animal-to-human transmission, which is controlled by society organization. Would the pandemic have been so deadly and fast-developing worldwide under low-population levels, density, and travel habits (Fig. 1)? Probably not. In order to prevent future pandemics, which will most likely happen because we have eradicated only the symptomatic virus, we should adopt a more oriental, holistic strategy that considers that the good functioning of any system depends on the good interaction of all its elements, summarized in the term 'harmony.' Practically, all societal and environmental factors controlling the pandemic should

Qianqian Wang and Jie Han have contributed equally to this work.

Jie Han

jiehan@xjtu.edu.cn

1 Institute of Global Environmental Change, School of Human Settlements and Civil Engineering, Xi' an Jiaotong University, Xi' an 710049, People's Republic of China

2 School of Water Conservancy and Civil Engineering, Northeast Agricultural University, Harbin 150030, Heilongjiang, People's Republic of China

3 Aix-Marseille University, CNRS, IRD, INRAE, CEREGE, 13100 Aix en Provence, France

4 State Key Laboratory of Multiphase Flow in Power Engineering, Xi' an Jiaotong University, Xi' an 710049, Shaanxi, People's Republic of China be studied. Here, we discuss viral transmission, imperfect protection, population density, and urbanization to unveil societal factors controlling pandemics, and to propose societal changes, such as an urban exodus, that would help prevent future pandemics.

\section{Viruses travel fast}

The World Health Organization (WHO) declared the novel coronavirus disease (COVID-19) a pandemic on 13 March 2020. As of 15 October 2021, nearly 240 million confirmed cases of COVID-19, including nearly five million deaths, have been reported around the globe (WHO 2021a). Humanto-human transmission through respiratory droplets, aerosols, contact surfaces or fomites is the primary cause for the transmission of COVID-19 (Chen et al. 2021; Han and Zhang 2020; He et al. 2020; WHO 2020a). In addition, fecal transmission and contact with virus-contaminated frozen foods and packages can spread the coronavirus (Han and He 2021; Han et al. 2021).

Infectious agents, hosts, and environmental transmission are the prerequisites for the spread of an infectious disease in the population. Possible modes of transmission for SARS-CoV-2 include airborne, contact, fecal-oral, and others (CDC 2021a; WHO 2020b). All these transmission routes are dependent on human behavior. Through the airborne route, viral transmission occurs primarily through respiratory droplets and aerosols generated during coughing or sneezing by infected individuals ( $\mathrm{Li}$ et al. 2020; Zhou et al. 2021). Aerosols generally have smaller particle sizes, less than $5 \mu \mathrm{m}$, than the most respiratory droplets and can travel longer distances. A recent study reported that SARSCoV-2 could remain viable in aerosols for up to three hours at $21-23^{\circ} \mathrm{C}$, with a reduction in infectious titer from $10^{3.5}$ to $10^{2.7} \mathrm{TCID}_{50}$ per liter of air titer (TCID: median tissue culture infectious dose, van Doremalen et al. 2020). Similarly, SARS-CoV-2 maintained infectivity when suspended 

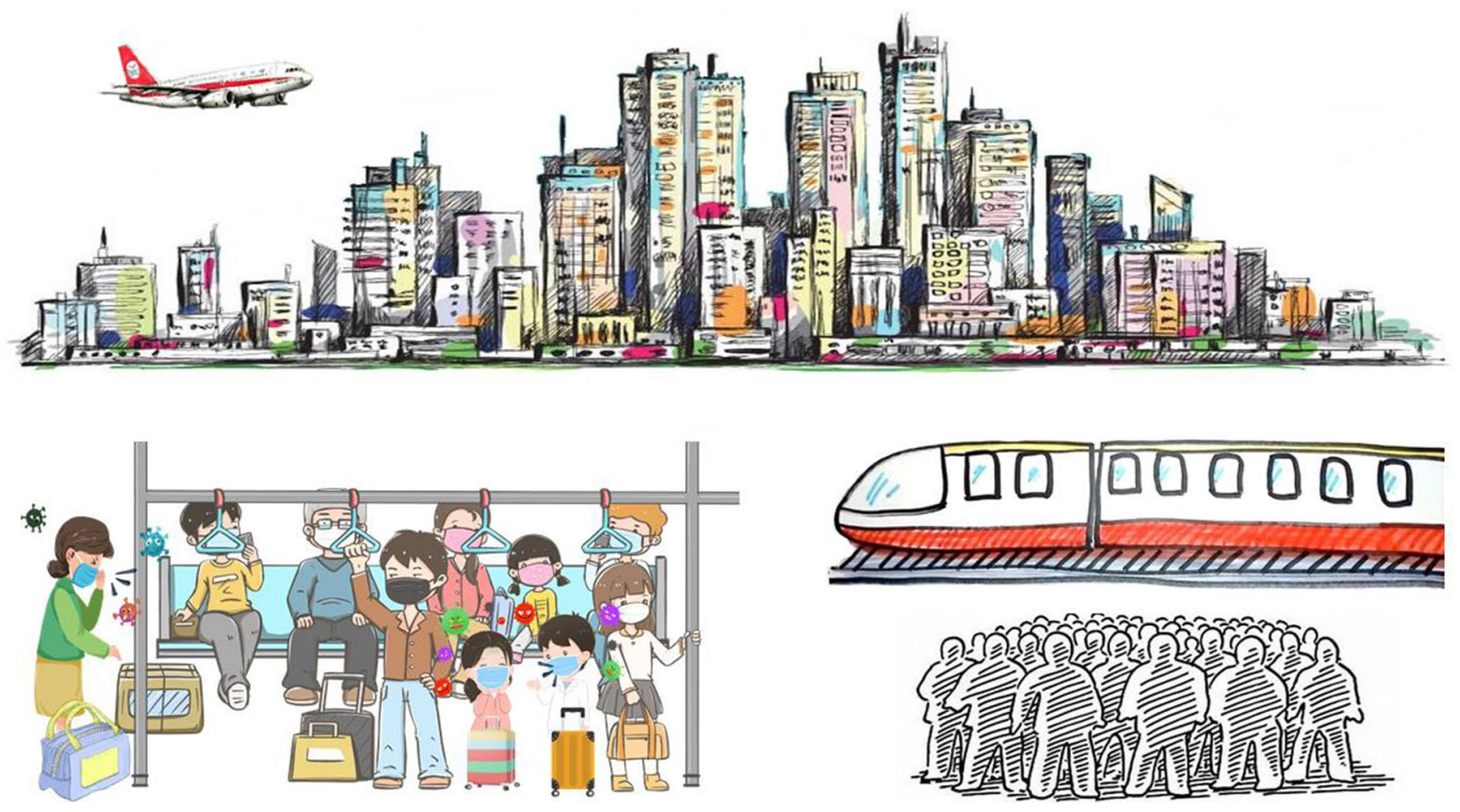

Fig. 1 The spread of infectious agents among humans is exacerbated by high population densities in modern societies. It is also impractical to maintain adequate social distances in certain environments, where wearing masks alone may not provide adequate protection for

in aerosols for up to $16 \mathrm{~h}$ at room temperature (Fears et al. 2020).

Transmission can also occur by viruses deposited on inanimate surfaces, which could infect people through their eyes, noses, and mouths after touching by hands. Moreover, SARS-CoV-2 viruses were found to show long persistence under low-temperature conditions, showing similar traits to SARS-CoV, which could survive up to two years at $-20^{\circ} \mathrm{C}$ (WHO 2020c). Researchers at the United States Army Medical Research Institute of Infectious Diseases (USAMRIID) reported that SARS-CoV-2 survived on swine skin for 14 days at $4{ }^{\circ} \mathrm{C}$ (Harbourt et al. 2020). There were also reports on re-emergent outbreaks of COVID-19 caused by virus-contaminated frozen foods and food packages in areas previously achieving local eradication of COVID-19 (Han et al. 2021). Overall, transmission is controlled not only by biological and physical factors, but also by human behavior.

\section{Imperfect masks}

Masks and face coverings are key measures to mitigate human-to-human transmission. Wearing face masks or cloth face coverings can considerably reduce the spread of respiratory pathogens. For healthy adults, wearing a cotton mask reducing the spread of respiratory pathogens. The mass availability of public transport and increased globalization with travel and trade activities may act synergistically and allow rapid spread of infectious agents in the world population

led to $20-40 \%$ reduction in virus intake by the wearer, while wearing a surgical mask reduced approximately $50 \%$ (Ueki et al. 2020). N95 particulate respirators showed the highest efficacy, enabling approximately $80-90 \%$ of reduction in virus intake at a social distance of $50 \mathrm{~cm}$. The protection is twofold. For infected individuals, wearing a cotton or surgical mask also blocked more than $50 \%$ of the viruses from their respiratory activities (Ueki et al. 2020).

Sometimes masks may not provide adequate means of protection. For instance, in crowded places people are very close to each other, and the situation is often worse in enclosed spaces with poor ventilation ( $\mathrm{He}$ and $\mathrm{Han}$ 2020; Wang et al. 2020). Expiratory droplets and aerosols can escape from masks due to imperfect sealing or fitting. Even when properly worn, medical face masks cannot completely block the transmission of respiratory virus droplets and aerosols (Ueki et al. 2020). Indeed, aerosols containing influenza viruses can easily go around the face mask and into the user's nose and mouth ( $\mathrm{He}$ et al. 2013). Moreover, when wearers are talking, 53\% of small respiratory droplets $(0.5-20 \mu \mathrm{m})$ are leaked from the top, $15 \%$ from the side, and $9 \%$ from the bottom of standard surgical masks (Cappa et al. 2021).

This is particularly relevant in situations where people wearing face masks are in close proximity to one another 


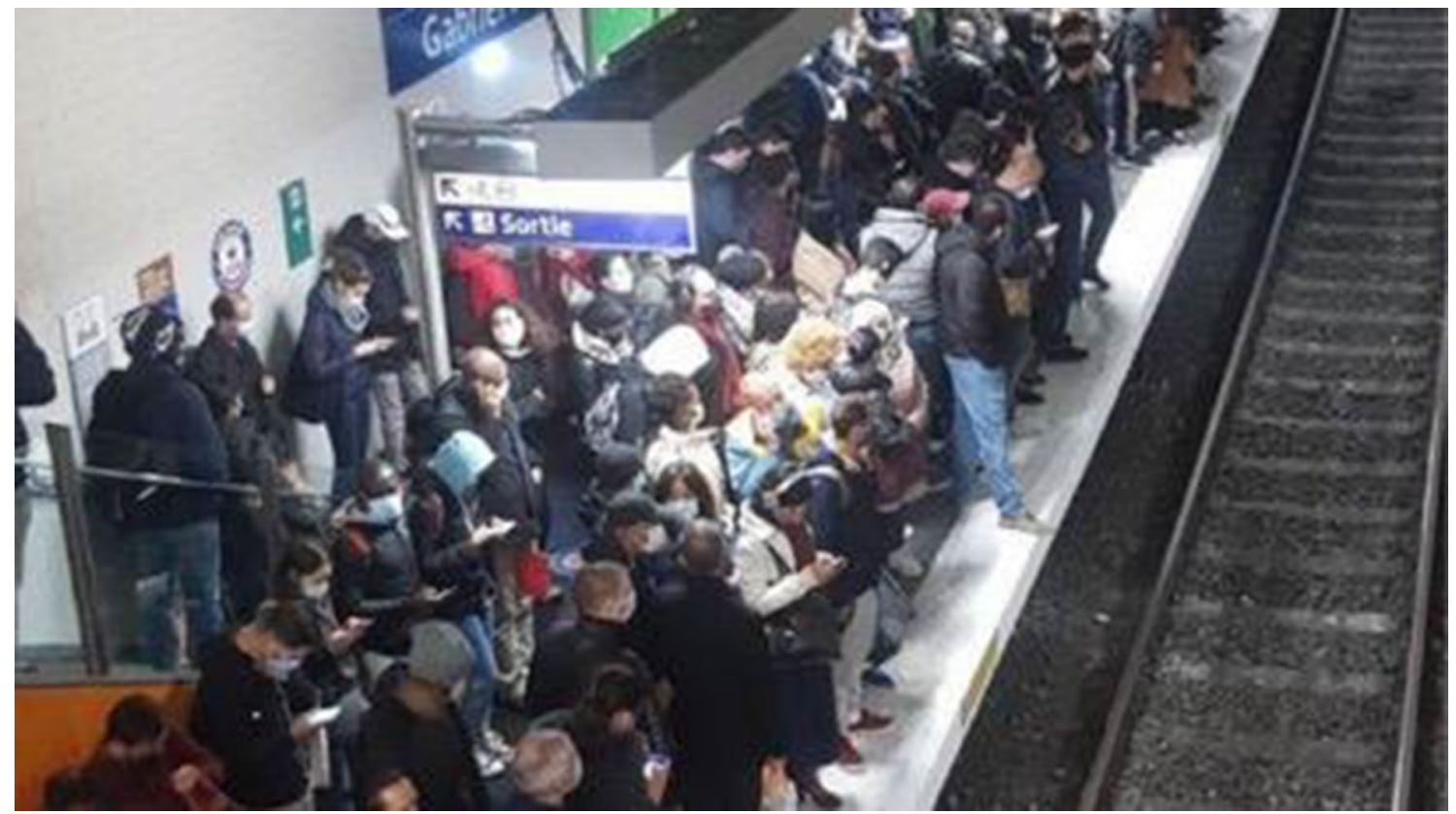

Fig. 2 A metro station as in Paris, France, during the COVID-19 pandemic in February 2021, showing a large crowd of people waiting for the subway train. Although most people were wearing face masks, the efficacy of protection is questionable in the very crowded space with

(Fig. 2). Such risks may be exacerbated by the recent emergence of the B.1.617.2 variant, also known as the 'Delta variant,' which has triggered a new wave of massive infections of COVID-19 (Kupferschmidt and Wadman 2021). As of 5 October 2021, the Delta variant had spread to 192 countries out of 194 WHO member countries (WHO 2021b), and became the dominant viral strain in the newly confirmed cases in the United States (CDC 2021b). A recent study showed that the respiratory viral load of people infected with the Delta variant was 1260 times higher than that of those infected with the original SARS-CoV-2 (Li et al. 2021). This makes it even more difficult to rely upon mask-wearing to prevent infection in places with inadequate social distancing and poor ventilation. Overall, imperfect mask protection and the proximity of people in public spaces have favored viral transmission.

\section{City hotspots}

Frequent social interactions are crucial for viral respiratory infections to develop into an epidemic or pandemic. Previous studies showed that seasonal infectious human diseases such as avian influenza are closely related to population aggregation and movement (Maya et al. 2014). This is a typical example where 'we knew,' but no change in society organization has been done to prevent future pandemics. High population density, frequent movement, and situations of little physical distancing. During peak hours, it is impossible for commuters to keep the required six-foot social distance in public transport vehicles and waiting areas. Photo: copyright Eric Lichtfouse 2021

close contact appear as major factors controlling the virus spread (Fig. 1). For instance, many studies have noted that population density, which is generally high in cities, strongly influences the likelihood of a disease outbreak (Connolly et al. 2021). High population density generally leads to closer contact and more interactions among residents, making cities the likely 'hotspots' during the early spread of emerging infectious diseases. Indeed, urban areas were initially hit much harder than suburban and rural areas in the COVID-19 pandemic. In the USA, cases and deaths were heavily concentrated in the metropolitan areas of New York, New Orleans, Boston, and Detroit during the early months of the pandemic (PRC 2021). The Lombardy region, which has the largest population and the highest population density in Italy, reported the highest incidence of coronavirus infection of any sub-national region in the country, whereas greener Mediterranean regions such as Sardinia, Calabria, and Basilica showed lower mortality rates (Cortright 2020; Lorusso et al. 2020; Roviello and Roviello 2021). Overall, highly populated areas showed higher transmission rates and cases, suggested that the future society should decrease population density in urban areas and moving people 'back' to the countryside. 


\section{No safe island}

Public transportation provides the means of mass human movement, which is an essential utility in the modern society but also favors the spread of infectious diseases. These efficient and extensive public transport networks help pathogens move rapidly between cities and countries, even continents. Such phenomena have been observed in previous human disease outbreaks, e.g., Ebola (Sharifi and Khavarian 2020). In the COVID-19 pandemic, the coronavirus outbreak hit densely populated urban areas first and hardest; then, quickly spread into the suburbs due to the busy connections in public transport (Tabernese and Mervosh 2021). Official statistics released in August 2020 suggested that 10\% of new infections in Greece were linked to tourism (Roache 2021). Zhang et al. (2020) found that the spread of COVID-19 in China was closely correlated to the routes and frequencies of domestic air, train, and coach services. Viruses reached more rural and exurban areas along with the human movements. Eventually, there are no 'safe islands' during a pandemic in the modern, interconnected human society.

\section{Deadly closed contact}

Close contact was defined as being within six feet of someone infected with the virus for a cumulative total of $15 \mathrm{~min}$ or more over a 24-h period (CDC 2021a). Situations of close contact are common in urban environments such as in elevators, cinemas, churches, shopping centers, and transportation hubs. Under those circumstances, it is often difficult to maintain the six-foot social distance (Wang et al. 2020), especially during peak hours (Fig. 2). During COVID-19, governments and public health authorities closed many public spaces to minimize non-essential contacts between people, and implemented symptom screening and the mandatory requirements of mask wearing in public transportation vehicles and facilities.

One of the exceptions, however, is religions activities (Pennisi 2011). For instance, the Kumbh Mela festival drew tens of millions of pilgrims across India to bathe in sacred rivers with celebrations and gathering for up to 48 days, which contributed to the surging numbers of COVID-19 infections between March and April 2021. On 7 May 2021, India registered 414,188 new COVID-19 cases, the highest daily figure in any country or territory since the outset of the COVID-19 (WHO 2021c). Italy, one of the catholic countries and the initial epicenter of the COVID-19 pandemic in Europe, also reported mass infections related to church activities (Mogi and Spijker 2021).

\section{Human migrations}

Historically, the emergence of pandemics and epidemics has coincided with the establishment of large urban settlements (Antoni et al. 2008; Ellwanger et al. 2021). The nineteenth century witnessed dramatic changes in the dynamic of urbanization. In Europe, two distinct phases of urbanization and human migration have occurred. The first phase, which was driven by industrialization and began in the $1850 \mathrm{~s}$, was characterized by the surging increase of urban population. Some industrial sectors became almost completely mechanized in the early mid-nineteenth century (Britannica 2021). Since more economic production was located in urban areas, people started to migrate from the countryside, e.g., farmers, to work near industrial plants, which was the beginning of the 'rural exodus' (Mercer 1965). Driven by better education, healthcare, infrastructure, and living conditions in cities, a great number of individuals continued to migrate to populated industrial areas (Mervyn 2014). Between 1805 and 1911, the proportion of the French population living in cities increased from 25 to $44 \%$, while in Germany the proportion of urban population increased from 30 to $60 \%$ (DHR 2021).

Since the 1960s, the industrialized nations in Europe have witnessed the second phase of mass human migration, known as 'suburbanization.' Many people started to migrate from rural areas and city centers to suburban areas. While European central cities sustained losses - to the order of more than three million residents-in reality suburbanization increased the total number of people living in the megacities. From the mid-1960s to the beginning of the 2000s, the metropolitan areas of Europe with populations over one million have gained about 24 million residents in total (Cox 2019). This trend continued into recent decades, although it has slowed down significantly. In 2021, there were 11.1 and 9.4 million of people living in the metropolitan areas of Paris and London, compared with only 7.4 and 8.2 million in 1960, respectively (WPR 2021).

A positive feedback loop exists between population growth and public transport services connecting metropolitan centers and suburban areas. On one hand, the mass availability of public transport provides a convenient means of daily commuting for people to travel between suburbs and city centers. On the other hand, the growing population living in city suburbs increases the demand for public transport services. Expressways, train stations, ferries, and airports are built to meet the demand of more people using public transport for daily commuting and inner-city traveling. Overall, a long-term and dramatic increase in the population living in urban and suburban areas has increased the risk of epidemics or pandemics. 


\section{A painful lesson}

Recent evidence has indicated that SARS-CoV-2 might have been quietly circulating in communities before the first known outbreak (He and Han 2021). For example, in Italy, researchers found traces of SARS-CoV-2 in municipal wastewater sampled at Milan and Turin on December 18, 2019 (La Rosa et al. 2021), suggesting that COVID-19 had already spread in their local population. Similarly, Fongaro et al. (2021) detected the coronavirus in sewage samples collected on 27 November 2019 in Brazil. An earlier study in Spain even detected SARS-CoV-2 in archived sewage samples collected in Barcelona in as early as March 2019 (Chavarria-Miró et al. 2020), several months before the first outbreak was reported in Wuhan, China (Ma et al. 2020). Regardless of the political debates over the geographic origin of COVID-19, the virus has spread to people all around the world in a quick and highly efficient manner.

These findings also raise the question that whether there will be other novel infectious agents, including zoonotic pathogens, circulating in the human population while they mutate, evolve, and eventually become epidemic or pandemic-causing agents. Although the answer is not immediately clear for SARS-CoV-2, evidence has been reported in several previous outbreaks of coronaviruses, directly supporting this hypothesis (He and Han 2021). There exists a strong link between anthropogenic activities and spillover of zoonotic pathogens (He et al. 2021). One evident example is that, in Peru, the destruction of thousands of acres of rainforests created new mosquito habitat and caused more than 120,000 cases of malaria in the late 1990s, compared with only less than 150 cases per year in the early 1990s (Shah 2009; Vittor et al. 2006). Climate change may also accelerate the transmission of infectious agents to and between humans (Beyer et al. 2021). Overall, it seems inevitable that humans will encounter other infectious disease outbreaks in a not distant future.

With two-thirds of the global population expected to live in cities by 2050, more people will be exposed to infectious agents in public spaces and through social interactions (Fulmer 2009). The global outbreak of COVID-19-along with the recent re-emergent outbreaks caused by its variants-has taught humans a painful lesson. The organization of modern human society must acknowledge these looming threats and adapt to the challenges and future uncertainties, through forward-thinking urban planning and by building more resilient cities, communities, and infrastructure. Since population density and movements are major controlling factors (Tatem 2014), de-centralizing the human society, therefore, will be a fundamental factor to attain a more robust societal structure when facing the threat of a fast-spreading pandemic.
There are realistic actions we can take in the near future to move toward this goal. Most human migrations are driven by resources. Young talents and labors seek work and opportunities, which are often more abundant in cities and industrialized regions. Spreading resources such as employments, education, and healthcare geographically, therefore, will fundamentally retard further migration of the population into large cities. Beijing, for instance, has been doing this for several years, and the population inflow has indeed slowed (Du 2021). In addition, governments and municipalities may offer incentives, e.g., tax breaks and rent subsidies for enterprises and employers to relocate to smaller cities, towns, and countryside while at the same time, invest in building more infrastructure, schools, and hospitals to accommodate the population inflow. The less expensive and more natural living environments are major factors attracting people to move to and settle in smaller cities and towns. While the COVID19 is not eradicated, people can make use of technologies to maintain productivity and avoid the risks of virus infection in public transport or work environments by working remotely from home. In the long term, we should build cities with more open space, spread-out infrastructure, and more even population densities in cities, suburbs, and surrounding towns. It is also helpful to provide more areas in buildings and public transport facilities to allow more social distances with means of using natural ventilation in air-conditioned enclosed spaces to lower the risk of transmission of human pathogens (Wang et al. 2020). Lastly, it is imperative to build more resilient waste management infrastructures to mitigate the possible transmission of infectious diseases in extreme weathers and natural disasters (Han and He 2021), which have become increasingly common due to anthropogenic activities and climate change.

Acknowledgements This work was funded by the Young Talent Support Plan of Xi' an Jiaotong University. The authors thank Ms. Xueting Yang for her assistance in collecting data and evidence in the early stage of preparing this manuscript.

\section{Declarations}

Conflict of interest The authors declare that they have no conflict of interest in this work.

\section{References}

Antoni T, Guillem T, Carolyn D (2008) The 1918 "Spanish Flu" in Spain. Clin Infect Dis 47(5):668-673. https://doi.org/10.1086/ 590567

Beyer RM, Manica A, Mora C (2021) Shifts in global bat diversity suggest a possible role of climate change in the emergence of SARS-CoV-1 and SARS-CoV-2. Sci Total Environ 767:145413. https://doi.org/10.1016/j.scitotenv.2021.145413

Britannica (2021) Industrial revolution. https://www.britannica.com/ event/Industrial-Revolution. Accessed 16 Oct 2021 
Cappa CD, Asadi S, Barreda S, Anthony SW, Nicole MB, William DR (2021) Expiratory aerosol particle escape from surgical masks due to imperfect sealing. Sci Rep 11:12110. https://doi.org/10.1038/ s41598-021-91487-7

CDC (2021a) Center for disease control and prevention. How COVID19 Spreads. https://www.cdc.gov/coronavirus/2019-ncov/preve nt-getting-sick/how-covid-spreads.html. Accessed 16 Oct 2021

CDC (2021b) Delta variant: what we know about the science. https:// www.cdc.gov/coronavirus/2019-ncov/variants/delta-variant.html. Accessed 16 Oct 2021

Chavarria-M G, Anfruns-Estrada E, Guix S (2020) Sentinel surveillance of SARS-CoV-2 in wastewater anticipates the occurrence of COVID-19 cases. medRxiv. https://doi.org/10.1101/2020.06. 13.20129627

Chen B, Jia P, Han J (2021) Role of indoor aerosols for COVID-19 viral transmission: a review. Environ Chem Lett 19:1953-1970. https:// doi.org/10.1007/s10311-020-01174-8

Connolly C, Keil R, Ali SH (2021) Extended urbanisation and the spatialities of infectious disease: demographic change, infrastructure and governance. Urban Stud 58(2):245-263. https://doi.org/10. $1177 / 0042098020910873$

Cortright J (2020) Cities and coronavirus: some thoughts. https:// cityobservatory.org/cities-and-coronavirus-some-thoughts-2/. Accessed 16 Oct 2021

Cox W (2019) Examining sprawl in Europe and America. https://reason.org/commentary/examining-sprawl-in-europe-and/. Accessed 16 Oct 2021

DHR (2021) Digital history reader. European history: can humans control the natural world? Urban landscapes and perceptions of nature. https://www.dhr.history.vt.edu/modules/eu/mod01_nature/ context.html. Accessed 16 Oct 2021

Du J (2021) Population of Beijing growing, aging. http://www.china daily.com.cn/a/202105/19/WS60a4ae56a31024ad0bac0067.html. Accessed 16 Oct 2021

Ellwanger JH, Veiga A, Kaminski VL, Valverde-VJM FA, Chies J (2021) Control and prevention of infectious diseases from a One Health perspective. Genet Mol Biol 44(1 Suppl 1):e20200256. https://doi.org/10.1590/1678-4685-GMB-2020-0256

Fears AC, Klimstra WB, Duprex P, Hartman A, Weaver SC, Plante KC, Mirchandani D, Plante JA, Aguilar PV, Fernández D, Nalca A, Totura A, Dyer D, Kearney B, Lackemeyer M, Bohannon JK, Johnson R, Garry RF, Reed DS, Roy CJ (2020) Comparative dynamic aerosol efficiencies of three emergent coronaviruses and the unusual persistence of SARS-CoV-2 in aerosol suspensions. medRxiv. https://doi.org/10.1101/2020.04.13.20063784

Fongaro G, Stoco PH, Souza DSM, Grisard EC, Magri ME, Rogovski P, Schorner MA, Barazzetti F-H, Christoff AP, de Oliveira LFV, Bazzo ML, Wagner G, Hernandez M, Rodriguez-Lazaro D (2021) The presence of SARS-CoV-2 RNA in human sewage in Santa Catarina, Brazil, November 2019. Sci Total Environ 778:146198. https://doi.org/10.1016/j.scitotenv.2021.146198

Fulmer J (2009) What in the world is infrastructure? PEI infrastructure investor (July/August), pp 30-32 https://30kwe1si3or29z2y020b gbet-wpengine.netdna-ssl.com/wp-content/uploads/2018/03/whatin-the-world-is-infrastructure.pdf

Han J, He S (2021) Urban flooding events pose risks of virus spread during the novel coronavirus (COVID-19) pandemic. Sci Total Environ 755(Pt 1):142491. https://doi.org/10.1016/j.scitotenv. 2020.142491

Han J, Zhang Y (2020) Microfiber pillow as a potential harbor and environmental medium transmitting respiratory pathogens during the COVID-19 pandemic. Ecotoxicol Environ Saf 205:111177. https://doi.org/10.1016/j.ecoenv.2020.111177

Han J, Zhang X, He S, Jia P (2021) Can the coronavirus disease be transmitted from food? A review of evidence, risks, policies and knowledge gaps. Environ Chem Lett 19:5-16. https://doi.org/10. 1007/s10311-020-01101-x

Harbourt D, Haddow A, Piper A, Bloomfield H, Kearney B, Gibson K, Minogue T (2020) Modeling the stability of severe acute respiratory syndrome coronavirus 2 (SARS-CoV-2) on skin, currency, and clothing. PLoS Negl Trop Dis. https://doi.org/10.1101/2020. 07.01 .20144253

He S, Han J (2020) Electrostatic fine particles emitted from laser printers as potential vectors for airborne transmission of COVID-19. Environ Chem Lett. https://doi.org/10.1007/s10311-020-01069-8

He S, Han J (2021) Biorepositories (biobanks) of human body fluids and materials as archives for tracing early infections of COVID19. Environ Pollut 274:116525. https://doi.org/10.1016/j.envpol. 2021.116525

He X, Reponen T, McKay RT, Grinshpun SA (2013) Effect of particle size on the performance of an N95 filtering facepiece respirator and a surgical mask at various breathing conditions. Aerosol Sci Technol 47(11):1180-1187. https://doi.org/10.1080/02786826. 2013.829209

He S, Shao W, Han J (2021) Have artificial lighting and noise pollution caused zoonosis and the COVID-19 pandemic? A review. Environ Chem Lett. https://doi.org/10.1007/s10311-021-01291-y

Kupferschmidt K, Wadman M (2021) Delta variant triggers new phase in the pandemic. Science 372(6549):1375-1376. https://doi.org/ 10.1126/science. 372.6549 .1375

La Rosa G, Mancini P, Ferraro GB, Veneri C, Iaconelli M, Bonadonna L, Lucentini L, Suffredini E (2021) SARS-CoV-2 has been circulating in northern Italy since December 2019: Evidence from environmental monitoring. Sci Total Environ 750:141711. https:// doi.org/10.1016/j.scitotenv.2020.141711

Li Q, Guan X, Wu P, Wang X, Zhou L, Tong Y, Ren R, Leung K, Lau E, Wong JY, Xing X, Xiang N, Wu Y, Li C, Chen Q, Li D, Liu T, Zhao J, Liu M, Tu W, Feng Z et al (2020) Early transmission dynamics in Wuhan, China, of novel coronavirus-infected pneumonia. N Engl J Med 382(13):1199-1207. https://doi.org/ 10.1056/NEJMoa2001316

Li B, Deng A, Li K-B, Hu Y, Li Z, Xiong Q, Liu Z, Guo Q, Zou L, Zhang H, Zhang M, Ouyang F, Su J, Su W, Xu J, Lin H, Sun J, Peng J, He J (2021) Viral infection and transmission in a large, well-traced outbreak caused by the SARS-CoV-2 delta variant. medRxiv. https://doi.org/10.1101/2021.07.07.21260122

Lichtfouse E (2009) Climate change, society issues and sustainable agriculture. Eric Lichtfouse. In climate Change, intercropping, pest control and beneficial microorganisms (Lichtfouse E. Ed.), Springer, pp.1-7, 2009, Sustainable Agriculture Reviews, Doi: https://doi.org/10.1007/978-90-481-2716-0_1. https://hal.archi ves-ouvertes.fr/hal-00442610/document

Lichtfouse E (2010) Society issues, painkiller solutions, dependence and sustainable agriculture. In sociology, organic farming, climate change and soil science (Lichtfouse E. Ed.), Springer, pp.1-17, 2010, Sustainable Agriculture Reviews, Doi: https://doi.org/10. 1007/978-90-481-3333-8_1. https://hal.archives-ouvertes.fr/hal00550433/document

Lorusso L, Precone V, Ferrari D, Ngonga GK, Russo AG, Paolacci S, Bertelli M (2020) Paraneoplastic neurological syndromes: study of prevalence in a province of the Lombardy region. Italy Clin Med Res 9(10):3105. https://doi.org/10.3390/jcm9103105

Ma J (2020) Coronavirus: China's first confirmed Covid-19 case traced back to November 17. South China morning post. https://www. scmp.com/news/china/society/article/3074991/coronavirus-chinas-first-confirmed-covid-19-case-traced-back. Accessed 16 Oct 2021

Maya BM, Rita BP, Michael G, Timothy MU, Jay B, Yang X, Yoshi G, Charlotte C, Nayer K (2014) Seasonal patterns in human A (H5N1) virus infection: analysis of global cases. PLoS ONE 9(9):e106171. https://doi.org/10.1371/journal.pone.0106171 
Mercer B (1965) Rural migration to urban settings: educational and welfare problems. Int Migr Dig 2(1):52-62. https://doi.org/10. 2307/3002980

Mervyn P (2014) Factors influencing migration and population movements-part 1. Future directions international strategic analysis paper. https://www.futuredirections.org.au/publication/factorsinfluencing-migration-and-population-movements/. Accessed 16 Oct 2021

Mogi R, Spijker J (2021) The influence of social and economic ties to the spread of COVID-19 in Europe. J Popul Res (Canberra). https://doi.org/10.1007/s12546-021-09257-1

Pennisi E (2011) Does religion influence epidemics? https://www.scien ce.org/content/article/does-religion-influence-epidemics-rev2. Accessed 16 Oct 2021

PRC (2021) Pew research center. The changing geography of COVID19 in the U.S. https://www.pewresearch.org/politics/2020/12/08/ the-changing-geography-of-covid-19-in-the-u-s/. Accessed 16 Oct 2021

Roache M (2021) Europe is seeing a surge in coronavirus cases. Are tourists the cause of the increase? https://time.com/5883317/ travel-coronavirus-europe/. Accessed 16 Oct 2021

Roviello V, Roviello GN (2021) Less COVID-19 deaths in southern and insular Italy explained by forest bathing, Mediterranean environment, and antiviral plant volatile organic compounds. Environ Chem Lett. https://doi.org/10.1007/s10311-021-01309-5

Shah S (2009) The spread of new diseases and the climate connection. https://e360.yale.edu/features/the_spread_of_new_diseases_the_ climate_connection. Accessed 16 Oct 2021

Sharifi A, Khavarian GAR (2020) The COVID-19 pandemic: impacts on cities and major lessons for urban planning, design, and management. Sci Total Environ 749:142391. https://doi.org/10.1016/j. scitotenv.2020.142391

Tabernese S, Mervosh S (2021) America's biggest cities were already losing their allure. What happens next? https://www.nytimes.com/ 2020/04/19/us/coronavirus-moving-city-future.html. Accessed 16 Oct 2021

Tatem AJ (2014) Mapping population and pathogen movements. Int Health 6(1):5-11. https://doi.org/10.1093/inthealth/ihu006

Ueki H, Furusawa Y, Iwatsuki-H K, Imai M, Kabata H, Nishimura $\mathrm{H}$, Kawaoka Y (2020) Effectiveness of face masks in preventing airborne transmission of SARS-CoV-2. mSphere 5(5):e00637-20. https://doi.org/10.1128/mSphere.00637-20

van Doremalen N, Bushmaker T, Morris DH, Holbrook MG, Gamble A, Williamson BN, Tamin A, Harcourt JL, Thornburg NJ, Gerber SI, Lloyd-Smith JO, de Wit E, Munster VJ (2020) Aerosol and surface stability of SARS-CoV-2 as compared with SARSCoV-1. N Engl J Med 382(16):1564-1567. https://doi.org/10. 1056/NEJMc2004973

Vittor AY, Gilman RH, Tielsch J, Glass G, Shields T, Lozano WS, Pinedo-Cancino V, Patz JA (2006) The effect of deforestation on the human-biting rate of Anopheles darlingi, the primary vector of Falciparum malaria in the Peruvian Amazon. Am J Trop Med Hyg 74(1):3-11

Wang X, Han J, Lichtfouse E (2020) Unprotected mothers and infants breastfeeding in public amenities during the COVID-19 pandemic. Environ Chem Lett 21:1-4. https://doi.org/10.1007/ s10311-020-01054-1

WHO (2020a) World health organization. Transmission of SARSCoV-2: implications for infection prevention precautions. https:// www.who.int/news-room/commentaries/detail/transmission-ofsars-cov-2-implications-for-infection-prevention-precautions. Accessed 16 Oct 2021

WHO (2020b) World health organization. Coronavirus disease (COVID-19): how is it transmitted? https://www.who.int/newsroom/q-a-detail/coronavirus-disease-covid-19-how-is-it-trans mitted. Accessed 16 Oct 2021

WHO (2020c) World health organization. Coronavirus disease 2019 (COVID-19) situation report 32. https://www.who.int/docs/defau 1t-source/coronaviruse/situation-reports/20200221-sitrep-32covid-19.pdf?sfvrsn=4802d0892. Accessed 16 Oct 2021

WHO (2021a) World health organization. Coronavirus (COVID-19) Dashboard. https://covid19.who.int/. Accessed 16 Oct 2021

WHO (2021b) World health organization. Weekly epidemiological update on COVID-19 - 5 October 2021. https://www.who.int/publi cations/m/item/weekly-epidemiological-update-on-covid-19---5october-2021. Accessed 16 Oct 2021

WHO (2021c) World health organization. Weekly epidemiological update on COVID-19-27 July 2021. https://www.who.int/publi cations/m/item/weekly-epidemiological-update-on-covid-19---27july-2021. Accessed 16 Oct 2021

WPR (2021) World population review. World city populations 2021. https://worldpopulationreview.com/world-cities. Accessed 16 Oct 2021

Zhang Y, Zhang A, Wang J (2020) Exploring the roles of high-speed train, air and coach services in the spread of COVID-19 in China. Transp Policy 94:34-42. https://doi.org/10.1016/j.tranpol.2020. 05.012

Zhou L, Ayeh SK, Chidambaram V, Karakousis PC (2021) Modes of transmission of SARS-CoV-2 and evidence for preventive behavioral interventions. BMC Infect Dis 21(1):496. https://doi.org/10. 1186/s12879-021-06222-4

Publisher's Note Springer Nature remains neutral with regard to jurisdictional claims in published maps and institutional affiliations. 